\title{
Public Health Aspects of Bacterial Drug Resistance in Modern Battery and Town/Village Poultry in the Tropics
}

\author{
By Adé A Ojenılı
}

Gastro-Enterology Divisıon, Department of Medicine, Rigshospitalet (National University Hospital), Copenhagen, Denmark.

\begin{abstract}
Ojeniyi, A: Public health aspects of bacterial drug resistance in modern battery and town/village poultry in the tropics. Acta vet. scand. 1989, 30, 127-132. - A correlation of antibiotic use and drug resistance was found among Escherichia coll strains isolated from battery poultry in the University of Ibadan Teaching and Research Farm. All the $E$ coll strains from battery birds were resistant to Tetracycline, Streptomycin and Sulphonamide (Sulphafurazole) by the disc sensitıvity test. In contrast, all the strains isolated from free range town and village poultry were sensitive to the range of drugs tested, while the Minimal Inhibitory Concentrations of the drugs against these free range isolates were the same as those for the control E. coll strain N.C.T.C. 10418. Ninety-eight to $100 \%$ of the strains from both battery poultry and from town/village birds were sensitive to Colistin, Chloramphenıcol, Nitrofurantoin and Nalıdixıc Acıd. Since antibiotic-resıstant Escherichia coll from anımal sources are known to be indistinguishable from those found in man, the indiscriminate use of antibiotics is potentially capable of giving rise to a higher incidence of intractable infection with resistant bacteria. These drug-resistant organisms may be transmitted from animal to man, and complicate the therapy of human diseases.
\end{abstract}

antıbacterials; resistant $E$ coll

\section{Introduction}

The widespread use of antibiotics, whether for therapy, prophylaxis or growth promotion, may lead to the emergence of antibiotic resistant bacterial populations in animals, including poultry (Slegel et al 1974, Smith and Tucker 1975, Linton 1977a \& b, Smith 1978, Ojenıyı 1980, Holmberg et al. 1984a). The more indiscriminately antibiotics are used, the higher the incidence of intractable infection with resistant bacteria may become. Since resistant organisms from animals can also colonise and infect human beings, the use or abuse of antibiotics in animals may complicate the therapy of human disease, quite apart from the fact that elimi- nation of sensitive bacterial strains and their replacement by antibiotic resistant organisms may lead to untreatable infections in the animals themselves. Tetracycline, one of the broad spectrum antibiotics, is widely and possibly uncritically used in poultry groups kept under the battery system in Ibadan, Nigeria and many other tropical developing countries.

Attempts have been made to evaluate the relationship between Escherichia coli strains of animal origin and human disease, and to assess the risk that they pose to man. Antibiotic resistant $E$. coli from animal sources have been found to be indistinguishable from those found in man, and it has also 
been found that the use of antibiotics in animals, for whatever purpose, contributes to the number of resistant Escherichia coll transmitted from animals to man (Linton 1977a \& b, Harbour et al. 1978, W.H.O. 1978). Antimicrobial resistant salmonella organism of animal origin has been shown to cause very serious clinical infections in human beings (Holmberg et al. 1984b).

In view of these findings, and because of the widespread local practice of incorporating antibiotics in poultry feeds, it was considered desirable to investigate the effect of antibiotic usage on Escherichia coll isolated from poultry in Ibadan and its environs.

\section{Materials and methods}

Cloacal swabs were collected from: -

(a) 500 birds at the University of Ibadan Teaching and Research Poultry Farm. These birds received antibiotics which were incorporated in their feeds.

(b) 100 birds caught in 3 villages - Aba Alaja, Aba Awusa and Aba Fakore on the outskirts of Ibadan city. These birds are kept under free range conditions and were not exposed to antibiotics.

(c) 200 chickens collected in Igbo-Ora and Idere towns in Ibarapa Division of Oyo State, Nigeria. These chickens are occasionally fed by their owners, otherwise they fend for themselves by scavenging around the houses in the townships.

\section{Bacteriological methods}

Isolation of Escherichla coli. Swabs were inoculated onto MacConkey agar, and after overnight incubation at $37^{\circ} \mathrm{C}$, isolated lactose fermenting colonies morphologically resembling Escherichia coli were subcultured to nutrient agar to check for purity. A single colony from each pure culture was then subcultured into peptone water, in- cubated for $4 \mathrm{~h}$ at $37^{\circ} \mathrm{C}$, and then used for biochemical tests (Cowan 1975) for identification.

Disc Sensitivity Tests. Pure cultures of Escherichia coli were inoculated into nutrient broth and incubated at $37^{\circ} \mathrm{C}$ overnight, after which the cultures were transferred into $1 \mathrm{ml}$ of sterile $1 / 4$ strength Ringer's solution, and the resulting suspensions which contained approximately $10^{6}$ organisms per $\mathrm{ml}$ were used to produce a lawn inoculum on $90 \mathrm{~mm}$ diameter petri dishes containing $25 \mathrm{ml}$ of Oxoid Sensitivity Test Agar (CM 261). This inoculum size produced dense, but just not completely confluent growth (W.H.O. 1961, Garrod et al. 1973).

The agar surface was allowed to dry, an Oxoid Multodisc UI 40569-236 was then placed in position, and the plates incubated at $37^{\circ} \mathrm{C}$ overnight. Resulting zones of inhibition were measured the following morning using calipers and a ruler in the absence of a planimeter. The Oxoid Multodisc contained the following chemotherapeutic agents: -

$\begin{array}{lrll}\text { Ampicillın } & 25 \mu \mathrm{g} & \text { Chloramphenıcol } & 50 \mu \mathrm{g} \\ \text { Colıstın } & 10 \mu \mathrm{g} & \text { Nalidixic Acıd } & 30 \mu \mathrm{g} \\ \text { Nitrofurantoin } & 200 \mu \mathrm{g} & \text { Streptomycin } & 25 \mu \mathrm{g} \\ \text { Sulphafurazole } & 500 \mu \mathrm{g} & \text { Tetracycline } & 50 \mu \mathrm{g}\end{array}$

\section{Mınımal Inhibitory Concentrations}

The Minimal Inhibitory Concentrations of the various drugs were estimated, using the Agar Dilution Method (Garrod et al. 1973).

Preparation of plates. Ampoules of antibiotics for clinical use were employed as starting materials as follows: -

(I) Ampicillin $250 \mathrm{~g}$ ampoule (Beecham B.P.)

(ii) Streptomycin $1 \mathrm{~g}$ ampoule (Glaxo B.P.)

(iii) Sulphadiazine $1 \mathrm{~g}$ ampoule (May \& Baker B.P.'

(iv) Tetracycline $250 \mathrm{~g}$ ampoule (Lederle B.P.)

For estimating Minimal Inhibitory Concentration of Chloramphenicol, the B.P. pure 
powder (Parke Davis) was weighed out and dissolved in alcohol to a known concentration which was then further diluted in sterile water as required.

To prepare the final plates, $99 \mathrm{ml}$ volumes of Oxoid Sensitivity Test Agar were melted and cooled to $45^{\circ} \mathrm{C}$. One $\mathrm{ml}$ of the appropriate antibiotic dilution was added, and the antibiotic-containing agar poured into each of the petri dishes.

The final antibiotic concentrations incorporated in the Sensitivity Agar were: -

Ampicillin: 32, 16, 8 and $4 \mu \mathrm{g} / \mathrm{ml}$.

Chloramphenicol: $32,16,8,4,2$ and 1 $\mu \mathrm{g} / \mathrm{ml}$.

Streptomycin: $32,16,8,4,2$ and $1 \mu \mathrm{g} / \mathrm{ml}$.

Sulphadiazine: $512,256,128,64,32,16,8$, $4,2,1$ and $0.5 \mu \mathrm{g} / \mathrm{ml}$.

Tetracycline: $8,4,2,1$ and $0.5 \mu \mathrm{g} / \mathrm{ml}$.

For each batch of tests, control plates of Sensitivity Agar without antibiotic were also prepared.

Estimation of Minimal Inhibitory Concentrations. Each E. coli strain was inoculated into nutrient broth, incubated at $37^{\circ} \mathrm{C}$ overnight, and then diluted in 1/4 strength Ringer's solution to give an approximate density of $10^{6}$ organisms. The control $E$. coli N.C.T.C. 10418 was included in each batch of tests.

Using a standard $0.01 \mathrm{ml}$ platinum loop, each strain was inoculated as a point inoculum onto each antibiotic-containing plate, and onto the control plate containing no chemotherapeutic agent. The inoculum size used contained approximately $10^{4}$ organisms.

All plates were incubated at $37^{\circ} \mathrm{C}$ overnight, after which they were examined for growth. The Minimal Inhibitory Concentration was taken as the lowest concentration of chemo- therapeutic agent which gave complete inhibition of bacterial growth.

\section{Results}

Agents for which Minimal Inhibitory Concentrations were not estimated

Colistin. All strains of E. coll isolated from village poultry were inhibited by the $10 \mu \mathrm{g}$ Colistin disc, with zone diameters ranging between 11 and $16 \mathrm{~mm}$. There were $2 \%$ of the $E$. coli strains isolated from poultry at the University of Ibadan Teaching and Research Farm which showed no inhibition zones, while the remaining $98 \%$ produced zone diameters ranging from 12 to $16 \mathrm{~mm}$. Ten replicate tests with the control E. coll N.C.T.C. 10418 gave zone sizes ranging from 14 to $16 \mathrm{~mm}$. All, except the few uninhibited strains from the University poultry, were therefore considered sensitive to this agent.

Nitrofurantoin. Findings were similar to those for Colistin, with all, except $2 \%$ of the strains from the University poultry giving inhibition zones ranging in size from 17 to $28 \mathrm{~mm}$ in diameter. Ten replicate tests using the control $E$ coll N.C.T.C. 10418 gave zone sizes ranging from 20 to $23 \mathrm{~mm}$ in diameter. All the strains, except the uninhibited few, which were not the same as the Colistin-resistant strains, were therefore considered to be sensitive to Nitrofurantoin.

Nalidixic Acid. All strains, without exception, gave zones of inhibition ranging between 18 and $25 \mathrm{~mm}$ in diameter. Ten replicate tests using the control E. coli N.C.T.C. 10418 gave zone sizes of inhibition ranging between 23 and $26 \mathrm{~mm}$ in diameter. All strains therefore, be these from University poultry, town poultry or village poultry, were considered to be sensitive to Nalidixic Acid. 
Table 1. Minımal Inhibitory Concentrations of various drugs against 500 Escherichia coli strains isolated from University battery poultry, 200 strains from town and 100 strains from village poultry.

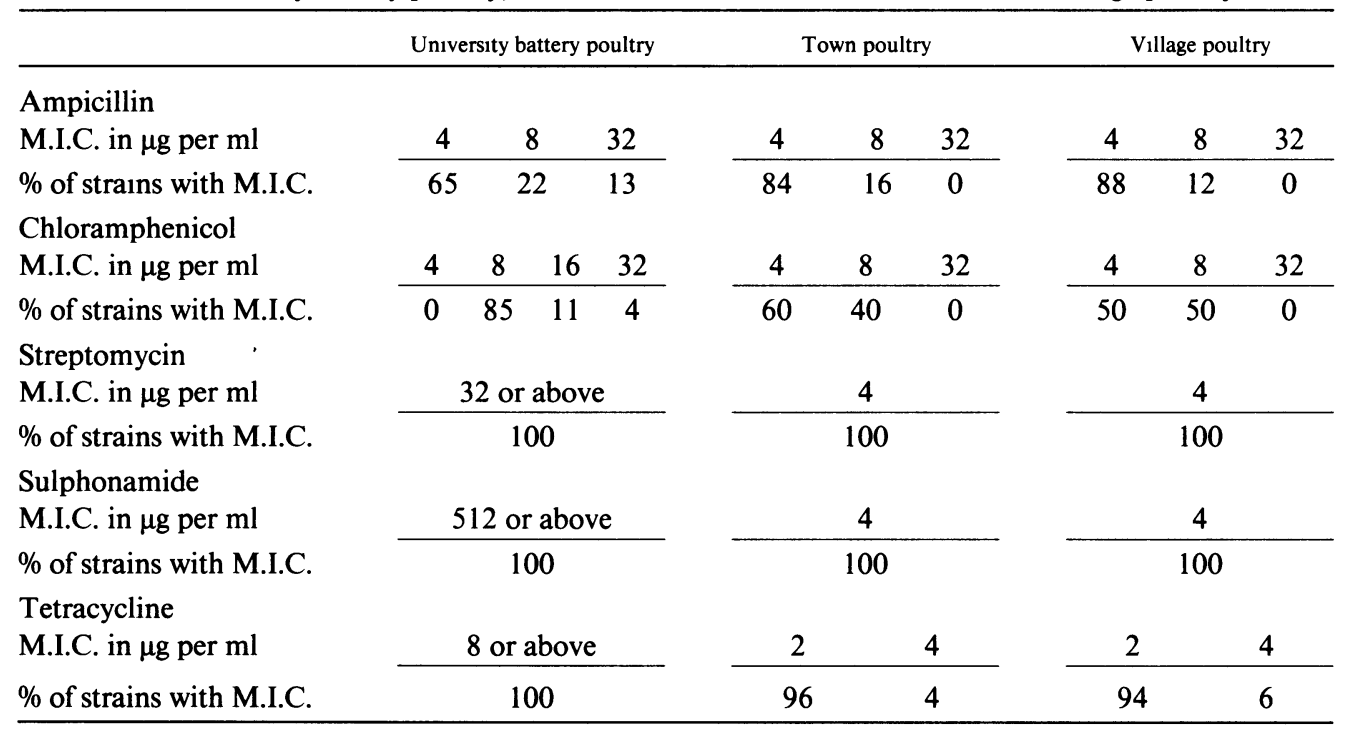

For Control Escherichia coll N.C.T.C. 10418, M.I.C. of Ampicillin = 8, Chloramphenicol = 8, Streptomycin $=4$, Sulphonamide $=4$, Tetracycline $=2 \mu \mathrm{g} / \mathrm{ml}$.

Agents for which Minimal Inhibitory Concentrations were estimated

The results of the Minimal Inhibitory Concentrations' estimation for Ampicillin, Chloramphenicol, Streptomycin, Sulphonamide and Tetracycline are shown in Table 1. It will be seen that all the strains from the University poultry were resistant to the highest concentrations of Tetracycline, Streptomycin and Sulphonamide tested, while all the strains from village poultry had the same M.I.C's as the control E.coli N.C.T.C. 10418 in the case of Streptomycin, Sulphonamide and Tetracycline.

All the village poultry strains had an M.I.C. of Ampicillin that was equal to, or less than that of the control E. coll while $22 \%$ of the University strains were resistant to 32 $\mu \mathrm{g} / \mathrm{ml}$, i.e. 4-folds of the M.I.C. for the control E. coli.

In the case of Chloramphenicol, all the vil- lage strains had M.I.C. values of $8 \mu \mathrm{g} / \mathrm{ml}$ or less. The M.I.C. of Ampicillin for the control E. coll was $8 \mu \mathrm{g} / \mathrm{ml}$. Among the strains from University poultry, there were $11 \%$ with an M.I.C. of $16 \mu \mathrm{g} / \mathrm{ml}$ which may be considered similar to that of the control E. coli strain from which it differs by only a single two-fold dilution, while 4 strains had M.I.C's of $32 \mu \mathrm{g} / \mathrm{ml}$ or greater.

All the strains from University poultry had M.I.C.'s of Tetracycline that were 8 times or more that of the control E. coll strain, while $98 \%$ of village strains had the same M.I.C. as that of the control E. coli N.C.T.C. 10418 strain.

\section{Discussion}

The widespread use of antibiotics, especially tetracycline, in battery poultry groups in a tropical country, like Nigeria, encourages 
the proliferation of antibiotic-resistant bacteria.

Administration of antibiotics to animals over long periods for prophylaxis favours the persistence of resistant strains long after the selection pressure has been removed (Harbour et al. 1978). The effect of such prolonged and continuous exposure helps to stabilise resistant organisms which then appear as integral part of the gastro-intestinal tract flora. Public Health authorities naturally feel a concern for the potential hazard to human health posed by the drug-resistant organisms in poultry since these oranisms are regularly excreted in large numbers in the birds' faeces (Howe et al 1976) and can reach man through poultry products (Burton et al. 1974, Harbour et al. 1978). This is even more significant in the tropical developing countries where drugs are very easily available without prescription and are rather indiscriminately and uncritically used. Stricter veterinary and pharmacy control of drugs is advocated.

\section{Acknowledgement}

I wish to express my gratıtude to Professor David G. Montefiore, Ag. Provost, College of Medicine, University of Ibadan, who made laboratory facilities available to me in the Department of Medical Microbılogy, University College Hospital, Ibadan, Nigena.

\section{References}

Burton CC, Hirsh DC, Blenden DC, Ziegler JL The effects of Tetracycline on the establishment of Escherichia coll of animal origin and IN VIVO transfer of antibiotic resistance in the intestinal tract of man. In "The Normal Microbial Flora of Man". Edit. Skinner, F. A. and Carr, J. G. Academic Press Inc. New York, N.Y. 1974, p. 241-253.

Cowan ST Cowan and Steel's Identification of Medical Bacteria. 2nd Ed. Cambridge University Press 1975.
Garrod LP, Lambert HP, O'Grady F. Antibiotic and Chemotherapy. 4th Ed. E. \& S. Livingstone, Edinburgh and London 1973.

Harbour HE, Abell JM, Cavanagh P, Clegg PG, Gould CM, Ellis P, Pyke M, Rilley CT, Laver $U$. Salmonella - the food poisoner. Brit. Assoc. Adv. Sci. Clumbury Cotterel Press. Berkhamsted, Herts, 1978.

Holmberg SD, Osterholm MT, Senger KA, Cohen $M L)$ Drug resistant salmonella from animals fed antimicrobials. New Eng. J. Med. 1984a, $311,617-622$.

Holmberg SD, Wells JG, Cohen ML. Animal-toMan transmission of antimicrobial-resistant salmonella. Investigations of U.S. outbreaks 1971-1983. Science 1984b, 225, 833-835.

Howe K, Linton AH, Osborne AD. The effect of tetracyclıne on the coliform gut flora of broiler chıckens with special reference to antibiotic resistance and O-serotypes of Escherichia coll J. Appl. Bacteriol. 1976, 41, 453-464.

Linton $A H$ Antibiotic Resistance: The present situation reviewed. Vet. Rec. 1977a, 100, 354360.

Linton $A H$ Antibiotics and Antibiosis in Agriculture. Proceedings of the University of Nottingham, School of Agriculture 1977b.

OJenıyl Adé A Epidemiology of Avian and Human Salmonellosis and Coliba cillosis in Ibadan and Environs. Dr. Phil. Thesis. College of Medicine Medical Library, University of Ibadan, Nigeria 1980.

Siegel D, Huber WG, Drysdale S: Human Therapeutic and Agricultural uses of antibacterial drugs and resistance of the enteric flora of humans. Antimicrobial Agents \& Chemother. 1975, 8, 538-543.

Siegel D, Huber WG, Enloe $F$. The continuous non-therapeutic use of antibacterial drugs in feed and drug resistance of gram-negative enteric florae of food-producing animals. Antimicrobıal Agents \& Chemother. 1974, 6, 697701.

Smith $H W \cdot$ Oral administration of neomycin to chickens experimentally infected with Salmonella typhimurium. Vet. Rec. 1978, 102, 354 356. 
Smith $H W$, Tucker JF. The effect of antibiotic therapy on the faecal excretion of Salmonella typhımurium by experimentally infected chickens. J. Hyg. (Camb.) 1975, 75, 275-292.

World Health Organisation. Standardisation of methods for conducting microbic sensitivity tests. 2nd. report, World Health Organisation Technical Report Series No. 210. W.H.O., Geneva 1961.

World Health Organisatıon. Surveillance for the prevention and control of health hazards due to antibiotic-resistant enterobacteria. World Health Organisation Technical Report Series No. 624. W.H.O., Geneva 1978.

\section{Sammendrag}

Konsekvensen for det offentllges sundhed af lagemiddelresistens hos bakterler blandt burhøns og losgående landsbyhons $\mathrm{l}$ troperne

Blandt moderne fjerkræhold i Nigeria forekom der Escherichia coll, der var resistent overfor streptomycin, tetracyclin og sulfonamider (sulfafurazol) i modsætning til $E$ col isolater hidrørende fra fritgående landsbyhøns, der alle var følsomme for samme antimikrobielle midler. Mellem 98 og $100 \%$ af isolaterne, fra såvel moderne fjerkræhold som fra landsbyhøns var følsomme overfor colistın, kloramfenikol, nalidixinsyre og nitrofurantoin. De minimale hæmningskoncentrationer (MIC) af diverse antibiotika og kemoterapeutika overfor landsbyhøns' $E$ coll var de samme som for standard E. coll N.C.T.C. 10418. For moderne fjerkræholds $E$ coll derimod havde $13 \%$ af dem MIC af Ampicillın på $32 \mu \mathrm{g} / \mathrm{ml}(4 \times$ MIC for standard E. coll), for kloramfenıkol havde $11 \%$ MIC på 16 $\mu \mathrm{g} / \mathrm{ml}$ og $4 \%$ havde $32 \mu \mathrm{g} / \mathrm{ml}(2 \times$ henholdsvis $4 \times$ MIC for standard $E$ coli), for streptomycin var end ikke $32 \mu \mathrm{g} / \mathrm{ml}(8 \times$ MIC for standard $E$ coli $)$ nok til at hæmme organismerne. Ligeledes var MIC af sulfonamid høj, $512 \mu \mathrm{g} / \mathrm{ml}(128 \times$ MIC for standard $E$ coli) og for tetracyklins vedkommende var MIC på $8 \mu \mathrm{g} / \mathrm{ml}$ ( $4 \times$ MIC for standard $E$ coli).

$\mathrm{Da}$ antibiotikaresistente animale $E$ coll vanskeligt kan skelnes fra de, der forekommer hos mennesker, kan ukritisk brug af antimikrobielle midler hos husdyrene medføre en højere incidens af langvarige og svært behandlelige infektionssygdomme såvel hos dyr som hos mennesker.

(Received February 29, 1988; accepted June 29, 1988)

Reprints may be requested from: Ade Ojeniyi, Telemarksgade 9, DK-2300 Sundby, Copenhagen, Denmark. 